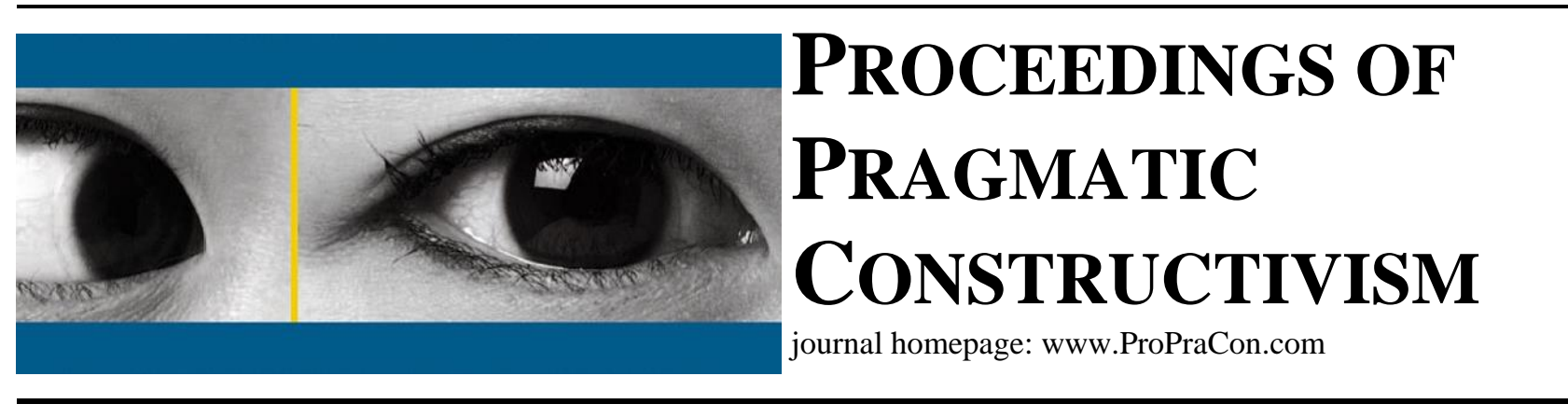

\title{
Change, concepts and the conceptualising method
}

\author{
Lars Bo Henriksen \\ Professor \\ Department of Development and Planning, Aalborg University \\ Vestre havnepromenade 5, DK-9000 Aalborg, Denmark; lbh@plan.aau.dk
}

\begin{abstract}
When looking for theories and methods in social science able to describe and understand changes, pragmatic constructivism offers some possibilities in doing exactly that. Research on pragmatic constructivism requires dialogues with actors in the field and an emphasis on language and language development. Concepts and concept development therefore plays a very central role in any researchers effort to describe and understand changes in language games and life worlds. In this essay I will take a closer look the concept of concepts and at concept formation. Through an analysis of Nørreklit's (1973) ideas of concepts as properties and Gadamer's (1962) ideas of concept formation, it is concluded that concept development are present in everyday life as well as a research method. The difference between the two is the accidental processes of everyday life, while research methods require a conscious application of concept development.
\end{abstract}

Keywords: Pragmatic constructivism; concepts as properties; concept formation.

\section{Introduction}

Social science, and especially social science with focus on changes in social settings, requires theories and methods that are actually able to describe and understand changes as changes. Theories and methods must therefore be able to capture the processive character of changes in social settings. In this article I argue that pragmatic constructivism, with its theory of reality and conceptualising method, is able to do exactly that. With an emphasis on language games and life worlds and changes in both language games and life worlds, it is possible to follow the ways in which actors carry out their actions (Arendt, 1958) and alter their life worlds. In this article, I take a closer look at language, concepts and the formation of concepts in the process of changes, as concept formation is where the actors actively show their efforts to change the current states of affairs.

Concepts are a form of both knowledge and capabilities, which we have, so that we, with words, can describe and understand, hold on to, realities and life worlds. We therefore need good concepts in order to understand, to know and to do. Conceptualisation and the conceptualising method are about creating useful concepts. This can be done in several ways: in the following I propose a strategy for conceptualising - a 'conceptualising method' (Nørreklit, 1978) and I explore the problems of how to conceptualise. In the actor-reality approach (Henriksen et al., 2004; Nørreklit, 2014, Nørreklit et al, 2016a) the conceptualising method plays a pivotal role. But how does this process of conceptualising work in a real life research setting?

The phenomena we deal with are the events forming the everyday lives of living people and how they solve problems through creation of new concepts? Further, how do we, as researchers, investigate this process of conceptualisation and how do we ourselves create new concepts and give new meaning to old ones in the course of the research process? Our task now is to search for ways of making a valid and reliable account of the conceptualising method and to be able to present such an account in concepts, while describing the process. In doing so here I investigate the concept of concept and of conceptualisation. That is, how can we understand concepts and how do we 
conceptualise - create concepts and what can we do with them? I follow Nørreklit's conceptualising method here (Nørreklit, 1973, 1978; Henriksen et al., 2004; Nørreklit et al, 2016b)). The core idea is to take ordinary words from our everyday conversations and turn them into social scientific concepts. Concepts are words with meaning and in our case how do we turn the equivocal words into rich concepts. I follow Nørreklit (1973) in describing concepts as something we possess and can do things with. Concepts, in this sense, are vital to our language games, to our ability to act and change things, and to our ways of understanding the world and our realities. For comparative purposes, I also draw here on Gadamer's (1962) ideas of concept formation, as concepts are both stable and changeable, or as Gadamer puts it, speculative and dialectical. First I turn to the question of concepts.

\section{Concepts and conceptualisation - The concept of concept}

What is in a concept? What is a concept? How do they function, how do we use them and how do we develop concepts, i.e., conceptualise? In order to respond to the question concerning conceptualisation I make what might seem like a detour and start out with a brief discussion of the concept of 'reality'. The study of everyday life is concerned with the actions of living people in their ordinary everyday lives. The problem here is how we understand and represent these actions in a way that is both valid and reliable and capable of developing concepts that actually work (virker) when we want to understand and represent. People's lives are lived in time; this is consequently a process and has to be, therefore, described as a process. These actions and lived lives are captured in the Danish concept of 'virke' (Nørreklit, 2009, p. 276). In the Danish and German languages we can use the concept 'virke' or 'wirkung' (see also Heidegger 1977, pp. 158). These words describe the actions of actors. They have no direct equivalent in English, but could be translated into action, work, activity, effort, functions. As we see, it can be both a verb and a noun. What the actor is doing is 'et virke', like a job or profession (a noun) and something 'virker' (a verb), means it is ok, it works, it is allright. If we take the example of an engineer it is exactly the 'virke' that we are interested in - what is the engineer doing when he is doing this activity called engineering. In this way engineering is a profession, a 'virke' (a noun) and engineering works, 'virker’ (a verb), when the engineer is successful in her profession (Nørreklit, 2013, p. 10).

With a point of departure in this 'virke' there are several points that need to be made. First of all, if a concept like 'engineering' describes a process, which it is, we are heading in the right direction if we describe engineering as a 'virke', as 'virke' also has the kind of processive character we are seeking. Secondly, the concept of 'virke' is also found in the Danish word 'virkelighed' or the German 'Wirklichkeit'. These concepts are just as directly un-translatable as 'virke' itself. 'Virkelighed' is often translated into 'reality', but they have very different roots. 'Virkelighed' is rooted in 'that which works', an activity, while 'reality' is rooted in the latin, 'reas' or 'res', meaning 'thing'. So, we have a difference between what works (virke, virkelighed) and what is (real, reality), between a process and something thingly, stable and not at all process-like or time related.

A reality may also be the way in which an actor understands the world. This provides us with another understanding of reality as 'virkelighed' (Nørreklit, 2004, pp. 31). From social science we are familiar with the concept of worldview. A reality is then the worldview that makes it possible for the actor to understand and act (virke) in his world and do what he wants to do according to his 'virke' (Henriksen et al., 2004). Describing and understanding this reality is the purpose of the social sciences and the humanities; these realities (virkelighed, Wirklichkeit, worldview) are an important and constitutive part of any actor's life world. The researcher then looks for the logics operating in this reality, for what would count as facts, and how these facts are constructed and consequently what values are included in the reality/worldview (as 'virkelighed'). Access to this reality is through communication (Henriksen et al., 2004; Nørreklit et al, 2016b); that is, through stories, narratives and observations of actions, through dialogues. Through communicating we also reveal our reality and the way this reality guides our actions, the way in which we think the world functions (virker).

Following this necessary detour through reality as 'virkelighed' we can now return to the concept of concept and elaborate on why it is so important for our investigations and research. Concepts are words with content and concepts are necessary if we want to understand actors' realities (virkelighed) and life worlds. If we once again turn to translations into Danish or German, we learn that concept is called 'begreb’ (Danish) or 'Begriff' (German). Both words literally meaning 'to hold on to something' or to 'grab something'; it is a metaphor for using words to grab something with words or to hold onto something with words. 'Begreb' in Danish can then mean 'to know something'; we can say 'to have 'begreb om' which means to know something. It can also be used negatively, such as in the sentence 'you do not have 'begreb' about ...' meaning ‘you haven't got a clue', so in this sense 'begreb' is about understanding, knowledge and knowing - to have 'begreb' is to understand and to know something. In older Danish we could also use 'begreb' instead of 'doing'. A sample sentence could then be 'he is in 'begreb' with ...' meaning he is doing ... something. With this we see that there is a connection from 'begreb' to understanding, knowing and doing and taken 
literally 'begreb’ denotes some kind of close connection between concept and some kind of phenomenon - to grab something - with words.

Concepts, then, are about understanding, knowing and doing - with good concepts we can grab phenomena and hold on to them. With good concepts we can describe and understand realities and life worlds and we can, consequently, do things. Concepts may now be viewed as something we have and can do things with, and as a form of capabilities or skills; as noted above, concepts may also be used negatively. Without concepts we know nothing and can, therefore, do nothing (Nørreklit, 1973).

\section{Concepts and abstractions}

We can now distinguish between abstractions and concepts (Henriksen et al., 2004, p. 22; Nørreklit, 2004, p. 34). The word 'yellow' is an abstraction which describes a colour, and therefore necessary for any communication, but insufficient for describing realities. For the latter we also need concepts. Concepts actively describe realities with their facts, logics, and values. If any dimension is missing it is not a concept, but merely an abstraction. Concepts are of a different nature to abstractions. Concepts should be precise descriptions of realities, preferably with an unequivocal meaning, freed from ambiguities and the possibility of misinterpretations; especially so for researchers if we wish to claim these as social scientific concepts. Of course we also use concepts in our everyday conversations; very often, however, these are ambiguous and often the reason for misunderstandings such as when concepts are used differently in different language games. The purpose of a scientific or social scientific investigation, therefore, is to seek to remove as many ambiguities as possible. This is a very ambitious goal, as most concepts of any significant interest have an aporic character (e.g., time, life, truth, etc.). Such challenges should not deter us from trying and through our research efforts using the conceptualisation approach presented here create knowledge and concepts (Nørreklit, 1978, p. 25; Henriksen et al., 2004, p. 22).

\section{Reality, concepts and language games}

From the description of concepts presented above, some might get the erroneous impression that concepts are images of phenomena in the world. This is decidedly not the case; it is very much to the contrary. The image theory of concepts states that words and concepts are imaging the world; it follows from this perspective that it should be possible to create a correspondence between world and language. This image theory has been heavily criticised, as that would require that we were able to double the world through language (Heidegger, 1996). Concepts would have a very different nature as this correspondence or doubling is quite simply impossible. Gadamer (1962) describes language as speculative and dialectical. Speculative refers to the stable character of language. Speculative is used in the original meaning of the word as a mirror. Concepts are mirroring the world, not making images of it:
"The word 'speculative' here refers to the mirror relation. Being reflected involves constant substitution of one thing for another. When something is reflected in something, say, the castle in the lake, it means that the lake throws back the image of the castle. The mirror image is essentially connected with the actual sight of the thing through the medium of the observer. It has no being of its own; it is like an 'appearance' that is not itself and yet allows the thing to appear by means of a mirror image. It is like a duplication that is still only the one thing. The real mystery of a reflection is the intangibility of the image, the sheer reproduction hovering before the minds eye”. (Gadamer, 1992, p. 465)

It follows that the relation between concept and phenomenon is not an image, but a reflection. There is a relation, but it is not a direct copying. Gadamer then goes on to describe speculation as something that is the opposite of 'the dogmatism of everyday experience'. To speculate can mean to think hard on something:
If we now use the word 'speculative' as it was coined by philosophers around 1800 and say, for example, that someone has a speculative mind or that a thought is rather speculative, behind this usage lies the notion of reflection in a mirror. Speculative means the opposite of the dogmatism of everyday experience. A speculative person is someone who does not abandon himself directly to the tangibility of appearances or to the fixed determinateness of the meant, but who is able to reflect or - to put it in Heglian terms - who sees that the "in-itself" is a "for-me". (Gadamer, 1992, p. 466)

Speculation then becomes part of a question and answer dialectic where we speculate, that is, ask questions about the state of the world and realities. This is the hermeneutic experience with its question and answer logic. In this way speculation is very similar to the concepts of thinking, philosophising etc., the methods we use when we want to know 
more about unknown worlds and realities. In contrast to the idea of speculation stands the 'statement'. A statement tells us what the world and realities 'is' like. Period. No questioning, no doubt, no paradoxes, no openness. The world is like this or like that. Period. The statement is often preferred in social scientific discourses, e.g., in the form of the definition and a denotative language, but such a one-sided addiction to statements severely restricts our thinking and interesting questions, and important understandings, would simply never appear.

Returning now to the concept of concept, we see that a concept is a mirroring of phenomena in the world, but this mirroring is open to possibilities, to questions and is not fixed in an already decided, defined, meaning. In this way the concept somehow relates, mirrors, phenomena in the world and this is why we can recognise them and use them when we communicate; but this relation is also a speculative one, always questioned and subject to possible changes. It follows that concepts are both fixed and changeable.

\begin{abstract}
"But that means, on the other hand, that the general concept meant by the word is enriched by any given perception of a thing, which does more justice to the particularity of that act of perception. However certainly speaking implies using pre-established words with general meanings, at the same time, a constant process of concept formation is going on, by means of which the life of a language develops". (Gadamer, 1992, p. 429)
\end{abstract}

Gadamer describes the everyday formation of concepts as based on accidents and relations. As a way of creating scientific or social scientific concepts we cannot rest our research hopes and aspirations on accidents and relations. We need other means. The formation of a concept as a social scientific concept requires a method, a procedure, a strategy. This is not to say that there is a huge difference between everyday concept formation and what we can now term social scientific concept formation: they are basically the same. The difference lies in the attention paid to the process. Our everyday formation of concepts is, as Gadamer noted, accidental and relational and it happens almost unnoticed. Social scientific formation of concepts, on the other hand, is not an accidental process but should be a very conscious one. A process where we, as scientists, are able to follow, understand and at best recall the process in a special narrative called method. The question now becomes how do we create, change and use concepts in a known procedure, in a method?

\title{
5 Conclusions and consequences
}

Conceptualising is about language and how we, through language can hold on to certain phenomena. Following Gadamer we know that language is the medium through which we meet the world; language and world are inseparable to human beings (Sein das verstanden werden kann ist Sprache). This language, therefore, provides the doors to hold open when we want to describe and to understand what people are thinking and doing; to understand and describe their realities and their life worlds and the changes that are the results of all that.

The first step in a conceptualising method could be taking a closer look at the concept itself. What does it mean literally - what are its roots, what is its history? To aid analysis we can turn to etymology and the history of the word that we want to make into a proper concept. As noted above, the concept of concept has some interesting roots and some very diverse meanings that can be traced and these can inform us about possible uses of the concept.

We could analyse what happens when we translate a concept into other languages. As we saw with the concept of 'reality' noted above, it took on totally different meanings when translated into Danish and German. It even changed from a concept with a thingly character to a concept that connotes process - maybe even from a noun to a verb?

We could also see how other researchers and other research disciplines have used and conceptualised the concept, even though we should be aware of the mountains of abstractions called definitions. Use of a concept in very different language games can add to our understanding of a concept. The key point here is that etymology, history and translations can produce very interesting and informative insights, which can inform us of the possibilities that may lie in a concept. Finally, and not least importantly, we could and should investigate the field ourselves. Through dialogues with actors in the field it is possible to collect stories and narratives and develop concepts with all the characteristics described above.

With this we can now return to our initial question about a social science method that is able to describe and understand changes. Because if we, when in the field, are aware of the concepts and the formation of concepts, we stand a much better chance of capturing changes. And we might even be able, as researchers, to contribute to the development of good and reliable concepts that could assist the actors in the field and thereby give something back to the actors that hosted us in the first place (Henriksen et al 2004, pp. 158; Nørreklit et al, 2016b). 


\section{References}

Arendt, Hannah, 1958. The Human Condition. The University of Chicago Press; 2nd edition (1998).

Christensen, Jens, Ed. 2004. Vidensgrundlag for handling (Knowledge base for action). Aalborg University Press. Aalborg.

Gadamer, Hans Georg. 1962 (1992). Truth and Method. Crossroads.

Heidegger, Martin. 1927 (1995). Being and Time. Basil Blackwell.

Heidegger, Martin. 1996 (1957). The principle of reason. Indiana University Press.

Henriksen, et al. 2004. Dimensions of Change. Copenhagen Business School Press.

Nørreklit, Hanne; Morten Raffnsøe-Møller; Mitchell, Falconer. 2016a. A pragmatic constructivist approach to accounting practice and research. Qualitative Research in accounting and Management. Vol. 13. No. 3.

Nørreklit, Hanne; Nørreklit, Lennart; Mitchell, Falconer. 2016b. Understanding practice generalisation - opening the research/practice gap. Qualitative Research in accounting and Management. Vol. 13. No. 3.

Nørreklit, Lennart. 1973. Concepts: their nature and significance for metaphysics and epistemology. Odense University studies in philosophy. vol. 2.

Nørreklit, Lennart. 1978. Problem orienteret forskningspraksis og den reale virkeligheds constitution. (Problem oriented research practice and the constitution of the real reality). Aalborg University Press. Aalborg.

Nørreklit, Lennart. 2004. Hvad er virkelighed? (What is reality?) In Christensen, Jens (Ed) Vidensgrundlag for handling (Knowledge base for action). Aalborg University Press. Aalborg.

Nørreklit, Lennart. 2009. Konstruktion af sandhed (Construction of Truth). In Rasmussen \& Aarup Jensen: Læring og forandring (Learning and Change). Aalborg University Press.

Nørreklit, Lennart. 2009. Konstruktion af sandhed - sandhed som integration og læring (Construction of truth truth as integration and learning). In Rasmussen \& Aarup Jensen: Læring og forandring - Tværfaglige perspektiver. (Learning and Change - cross disciplinary perspectives. Aalborg. Aalborg University Press.

Nørreklit, Lennart. 2013. Reality as a construct: outline of a pragmatic constructivist perspective. Proceedings of Pragmatic Constructivism. Vol 3, No 2. 